\title{
Mapping of potential areas for landfill installation in the Metropolitan Region of Belém
}

Mapeamento de áreas potenciais para a instalação de um aterro sanitário na Região Metropolitana de Belém

\section{Paulo Eduardo Silva Bezerra '; Ádanna de Souza Andrade II; Milena Marília Nogueira de Andrade III}

\begin{abstract}
The production of solid waste in Brazil has increased considerably, with the creation of a great number of dumps. Several socio-environmental impacts results from this inadequate disposal. The present work had the objective to evaluate, based on environmental, economic and social criteria, possible favorable areas for the installation of a sanitary landfill in the Metropolitan Region of Belém (MRB), state of Pará. To this end, data were processed using a Geographic Information System (GIS). A map with potential areas for landfill installation in the MRB was created, based on the criteria and weights assigned to each variable through map algebra methods. The results showed four areas in the municipality of Santa Bárbara and Santa Izabel as favorable for installation of the project, with characteristics that meet the criteria established in legislation (NBR 13896/1997).
\end{abstract}

Keywords: Solid waste; Social and environmental impacts; Geographic Information System

\footnotetext{
' Universidade Federal do Pará, Belém, Brazil. pauloeduardoea@gmail.com

"Instituto Federal de Educação, Ciência e tecnologia do Pará, Belém, Brazil. adanna.eng.ambiental@gmail.com

III Universidade Federal Rural de Amazônia, Belém, Brazil. milenamarilia.andrade@gmail.com
} 


\section{RESUMO}

O Brasil tem registrado um aumento na produção de resíduos sólidos. Associado a isso, cresce o número de lixões por todo o país, bem como os impactos socioambientais decorrentes dessa disposição inadequada. Nesse sentido, esse trabalho tem como objetivo avaliar, a partir de critérios ambientais, econômicos e sociais, a melhor alternativa locacional para um aterro sanitário da região metropolitana de Belém (RMB), estado do Pará. Para alcançar o objetivo proposto, os dados obtidos foram processados em um Sistema de Informação Geográfica (SIG) e assim elaborado o mapa de aptidão das áreas potenciais para a instalação do aterro sanitário da RMB, a partir dos critérios e pesos atribuídos a cada variável com métodos de álgebra de mapas. Os resultados mostraram que 4 áreas são consideradas aptas no município de Santa Bárbara e Santa Izabel para a instalação do aterro sanitário, por atenderem aos critérios exigidos na legislação (NBR 13896/1997).

Palavras-chave: Resíduos sólidos; Impactos socioambientais; Sistema de informação geográfica.

\section{INTRODUCTION}

Population increase, rapid urban growth, and increasing access to products have led to greater consumption and consequent solid waste generation (LOURENÇO et al., 2015). At the same time, there is a growing concern with the preservation of natural resources and with the issue of public health associated with waste disposal. This, in turn, leads to an increasing claim of society for public policies to address these issues.

In Brazil, the National Solid Waste Policy (PNRS) (Law n. 12.305/2010) provides for integrated solid waste management, as well as environmentally sound management, under the premise of sustainable development. One of the options to avoid damage or risks to public health and safety and to minimize adverse 
environmental impacts is the final disposal of waste in landfills, observing specific operational rules (BRASIL, 2010). However, there has been an increase of garbage dumps in Brazilian municipalities, contrary to what is advocated by environmental legislation, since they are open dump sites whose creation was not based on technical choices (CORREIA et al., 2017). Among the environmental impacts of this inadequate waste disposal are the alteration of the physico-chemical composition of the soil and its contamination by leachate from decomposing organic matter present in the waste, and contamination of both surface and underground water sources (SILVA et al., 2012; SILVA et al., 2013).

A landfill is defined by NBR 8.419/1992 as a technique of disposal of urban solid waste in the soil that does not cause damage to public health and safety and minimize environmental impacts. This method is based on the application of engineering principles to confine solid waste to the smallest possible area and reduce it to the smallest allowable volume, covering it with a layer of earth at the conclusion of each workday (ABNT, 1992). With regard to the location of landfills, NBR 15849/2010 provides for the minimum conditions required in terms of location, design, implementation, operation and closure of small landfills for the final disposal of municipal solid waste (ABNT, 2010). The parameters considered are the topographic and geological conditions, existing soil types, vegetation, distance from water resources, minimum distance to population nuclei, available size, and useful life of the landfill, as well as costs of implementation (CORREIA et al., 2017).

The most favorable locations for implantation of sanitary landfills have been analyzed in previous works in Brazil and in the world considering criteria such as hydrography, conurbation areas, conservation units, slope, distance from roads, Permanent Preservation Area (PPA), land use and land cover, geology, soil type, and distance from archaeological sites (MOREIRA et al., 2016; FELICORI et al., 2016; REZENDE et al., 2015; NAS et al., 2010). In the state of Pará, in the Metropolitan Region of Belém (MRB), the problem of solid waste management in the municipality is old. For over more than 20 years, all the waste produced in the capital of Pará and some municipalities of the MRB were deposited in the Aurá landfill (located in Ananindeua). 
This landfill was originally built to work together with an incineration plant and a recycling and composting plant, but this never occurred and the area turned into an open dump, directly impacting the surrounding hidric resources (SANTO, 2014; DANTAS et al., 2015).

It is currently the municipality of Marituba that receives the waste produced in the capital of Pará (VASCONCELOS and SILVA 2017). However, the company responsible for the landfill committed several environmental irregularities and crimes, such as contamination of water, air and soil, which were exposed by the local population (JUNIOR and CORRÊA 2017). These authors also emphasize that the project has not yet been technically adapted to the norms established in the PNRS, especially with regard to the minimal distance required from nature reserves and groundwater. Therefore, the Marituba landfill can be considered a controlled landfill, which is defined as "a way to technically confine the collected waste without polluting the external environment, but without promoting the collection and treatment of leachates and the collection and burning of biogas" (ZVEIBIL, 2001). In this context, this work aims to contribute to a diagnosis of the best potential location for a potential landfill in the MRB based on environmental, economic and social criteria and geoprocessing techniques.

\section{MATERIAL AND METHODS}

\subsection{Study area}

The Metropolitan Region of Belém (MRB) is located in the state of Pará, has an area of 3,566 km², and consists of seven municipalities: Belém, Ananindeua, Marituba, Benevides, Santa Bárbara, Santa Isabel and Castanhal (IBGE, 2018). The municipality of Castanhal will not be considered in this study due to its greater distance from the municipalities of Belém and Ananindeua, which are the largest producers of solid waste. The distance of Castanhal raises the operating cost of the possible landfill. Thus, the study area of the present study includes the municipalities of Belém, Ananindeua, Marituba, Benevides, Santa Bárbara and Santa Isabel (Figure 1). 
Figure 1 - Location map of the Metropolitan Region of Belém

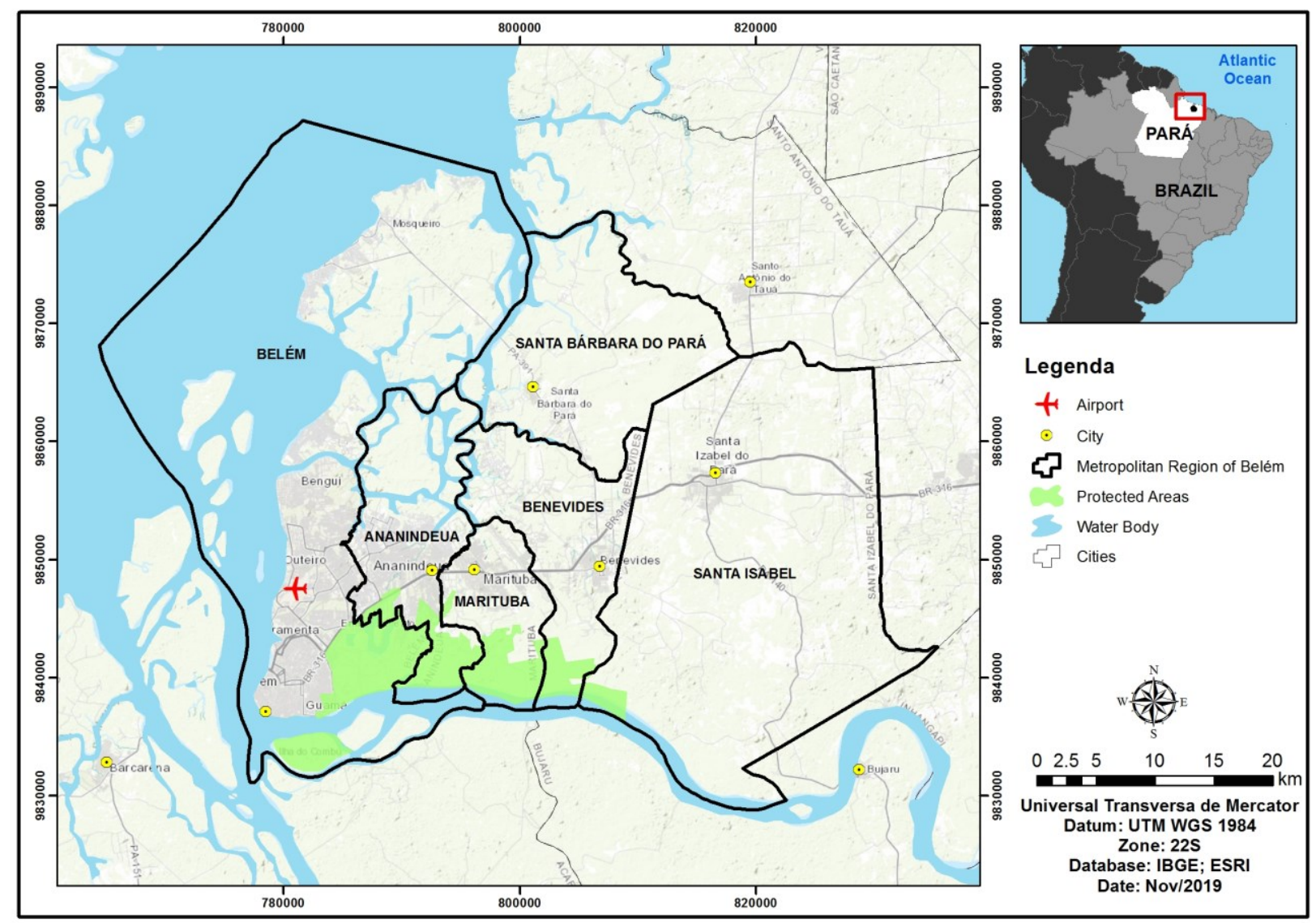

The study area had an estimated population of 2,292,758 inhabitants in 2018, according to IBGE (2018), and Belém, the state capital, had about $64 \%$ of these inhabitants, with 1,485,732 people. In terms of demographic density, the municipality of Ananindeua is the leader with 2,477 inhabitants $/ \mathrm{km}^{2}$, while Santa Bárbara has only 61.62 inhabitants/km².

The metropolitan area is located at the mouth of the Guajará Bay, composed of several rivers and islands, especially the Guamá river. The terrain is flat, with elevations ranging from 12 to 58 meters, and a relief characterized by fluvial plains and tablelands of Pará (COSTA, 2015). Four conservation units are present in the study area: Combu Island Environmental Protection Area (State Law n 6,083 of 11/13/1997), Environmental Protection of the Metropolitan Region of Belém (APA Belém) (State Decree $n^{\circ} 1,551$, of 03/05/1993, reworded by Decree $\left.n^{\circ} 1,329,02 / 10 / 2008\right)$, Utinga State Park (State Decree $n^{\circ} 1,552$, of 03/05/1993, reworded by State Decree $n^{\circ} 1,330$ of 
02/10/2008) and Metrópole da Amazônia Wildlife Refuge (Decree $n^{\circ}$ 2,211 of 30/03/2010).

Regarding pedology, the soils are classified as latosol, spodosol, gleysol and plintossol (IBGE, 2004). The geology of the region is characterized by the Barriers Group, Alluvial Deposits and Post-Barriers sediments (CPRM, 2013). According to the köppen classification, the region is in the Afi climate zone, characterized by a humid tropical rainforest climate. Rainfall is present throughout the year; the rainiest period is in December to May and least rainy, from June to November. The average temperature is $26^{\circ} \mathrm{C}$ and and the annual rainfall is $2870 \mathrm{~mm}$ (SANTOS, 2017).

\subsection{Criteria Used}

Environmental, economic and social criteria, based on NBR 13896/1997 and the Integrated Solid Waste Management Manual (ZVEIBIL, 2001), were considered for the analysis of potential areas for landfill installation. The environmental criteria used were: fauna attraction, protected areas, water body, slope, geology and pedology, and water table. In the economic criteria, the following variables were considered: access, landfill area, land use, and landfill useful life. In the social aspect, the urban area, estimated population, and solid waste production were used as criteria (Box 1).

Box 1 - Criteria for the selection of landfill sites

\begin{tabular}{|c|c|c|c|}
\hline \multicolumn{2}{|c|}{ Criterion/Variable } & Justification & Technical considerations \\
\hline \multirow[b]{2}{*}{ Environmental } & $\begin{array}{c}\text { Fauna } \\
\text { Attraction }\end{array}$ & $\begin{array}{l}\text { The waste disposal site attracts fauna, } \\
\text { especially birds, and this attraction can } \\
\text { cause problems related to the air. Thus, a } \\
\text { minimum distance from airports is } \\
\text { recommended (MORAES, FERREIRA \& } \\
\text { OLIVEIRA, 2010). }\end{array}$ & $\begin{array}{c}\text { It is necessary to respect a } \\
\text { distance of } 10 \mathrm{~km} \text { (Law } \\
12.725 / 2012)\end{array}$ \\
\hline & $\begin{array}{c}\text { Protected } \\
\text { Areas }\end{array}$ & $\begin{array}{l}\text { In the case of protected areas, according to } \\
\text { Law } 9,985 \text { of July } 18,2000 \text {, the National } \\
\text { System of Conservation Units (SNUC) } \\
\text { establishes the creation of buffer areas in } \\
\text { order to minimize environmental impacts. } \\
\text { Thus, a distance of } 3 \text { kilometers for } \\
\text { environmental protection áreas is } \\
\text { mandatory. }\end{array}$ & $\begin{array}{l}\text { SNUC recommends in its } \\
\text { Art. } 25 \text { the creation of a } \\
\text { buffer zone in conservation } \\
\text { units. The distance of } 3 \mathrm{~km} \\
\text { from protected areas } \\
\text { (protected areas, } \\
\text { indigenous lands, } \\
\text { Quilombola communities) } \\
\text { was established. }\end{array}$ \\
\hline
\end{tabular}




\begin{tabular}{|c|c|c|c|}
\hline & $\begin{array}{l}\text { Water } \\
\text { body }\end{array}$ & $\begin{array}{l}\text { Contamination of water bodies must be } \\
\text { avoided. }\end{array}$ & $\begin{array}{l}\text { A minimum distance of } 200 \\
\mathrm{~m} \text { from any water body and } \\
\text { also from the PPA, } \\
\text { according to law } \\
12.651 / 2012 \text { of the forestry } \\
\text { code, is recommended. }\end{array}$ \\
\hline & Slope & $\begin{array}{l}\text { Installation of landfills must take place in } \\
\text { flat areas, because the slope is directly } \\
\text { related to erosion and landslides } \\
\text { (LOURENÇO, 2015). }\end{array}$ & $\begin{array}{l}\text { Places with slopes greater } \\
\text { than } 1 \% \text { and less than } 30 \% \\
\text { are recommended, } \\
\text { according to NBR } \\
13.896 / 1997 .\end{array}$ \\
\hline & $\begin{array}{l}\text { Geology } \\
\text { and } \\
\text { pedology }\end{array}$ & $\begin{array}{l}\text { Geology and pedology are important for } \\
\text { determining soil purification and infiltration } \\
\text { rate. }\end{array}$ & $\begin{array}{c}\text { More impermeable soils and } \\
\text { rocks to resist infiltration } \\
\text { mainly of leachate are } \\
\text { recommended, according } \\
\text { to NBR 13.896/1997 }\end{array}$ \\
\hline & $\begin{array}{l}\text { Water } \\
\text { table }\end{array}$ & $\begin{array}{l}\text { Contact of groundwater with leachate must } \\
\text { be avoided. }\end{array}$ & $\begin{array}{l}\text { A depth of } 1.5 \text { meters } \\
\text { between the bottom } \\
\text { surface of the landfill and } \\
\text { the highest groundwater } \\
\text { level must be respected, } \\
\text { according to NBR } \\
13.896 / 1997 .\end{array}$ \\
\hline \multirow{4}{*}{ Economic } & Access & $\begin{array}{l}\text { Closer distance from roads favor potential } \\
\text { of areas for landfill installation }\end{array}$ & $\begin{array}{l}\text { A distance of } 100 \text { meters } \\
\text { from the highways must be } \\
\text { respected, according to } \\
\text { NBR } 13,896 / 1997\end{array}$ \\
\hline & $\begin{array}{l}\text { Landfill } \\
\text { area }\end{array}$ & $\begin{array}{l}\text { A certain landfill area is required for solid } \\
\text { waste disposal. }\end{array}$ & $\begin{array}{l}\text { The landfill area has to } \\
\text { correspond to population } \\
\text { size and waste production } \\
\text { (CARRILHO; CANDIDO \& } \\
\text { SOUZA, 2018) }\end{array}$ \\
\hline & Land use & $\begin{array}{l}\text { Most appropriate areas must be chosen to } \\
\text { install the landfill. }\end{array}$ & $\begin{array}{l}\text { Already deforested areas are } \\
\text { to be chosen for installation } \\
\text { (LOURENÇO et al., 2014) }\end{array}$ \\
\hline & $\begin{array}{l}\text { Landfill } \\
\text { useful life }\end{array}$ & $\begin{array}{l}\text { The useful life of the landfill is related to } \\
\text { the cost of the project. }\end{array}$ & $\begin{array}{c}\text { A minimum useful life of } 10 \\
\text { years is recommended, } \\
\text { according to NBR } \\
13.896 / 1997 .\end{array}$ \\
\hline \multirow{3}{*}{ Social } & $\begin{array}{l}\text { Urban } \\
\text { area }\end{array}$ & $\begin{array}{l}\text { Proliferation of diseases and strong odor } \\
\text { from the landfill must be avoided. }\end{array}$ & $\begin{array}{c}\text { A distance of } 2 \mathrm{~km} \text { for urban } \\
\text { perimeters and } 500 \text { meters } \\
\text { for small conglomerates } \\
\text { must be respected, } \\
\text { according to NBR } \\
13.896 / 1997 \\
\end{array}$ \\
\hline & $\begin{array}{l}\text { Estimated } \\
\text { population }\end{array}$ & $\begin{array}{l}\text { The population size must be determined } \\
\text { for a period of } 15 \text { years, according to the } \\
\text { useful life (NBR 13,896/1997). }\end{array}$ & $\begin{array}{c}\text { The minimum landfill area } \\
\text { must be determined (NBR } \\
13.896 / 1997)\end{array}$ \\
\hline & $\begin{array}{l}\text { Estimated } \\
\text { waste } \\
\text { production }\end{array}$ & $\begin{array}{l}\text { Total waste generation over a period of } 15 \\
\text { years, depending on the useful life of the } \\
\text { landfill. }\end{array}$ & $\begin{array}{c}\begin{array}{c}\text { The minimum landfill area } \\
\text { must be determined (NBR } \\
13.896 / 1997)\end{array} \\
\end{array}$ \\
\hline
\end{tabular}

Source: Adapted from NBR 13896 (1997); SHIMIDT (2016); CORREIA et al. (2017) 


\subsection{Data acquisition}

Data were collected from various sources and in digital raster and vector formats (Box 2; Figure 2). In the environmental criterion, fauna attraction information was extracted using a distance of $10 \mathrm{~km}$ from the airport, identified with the aid of Google Earth imagery. Information on protected areas was obtained from the Brazilian Institute of Environment and Renewable Natural Resources (IBAMA), and of water bodies from the Amazon Protection System (SIPAM).

Box 2 - Databases used in the research

\begin{tabular}{|l|c|c|c|}
\hline Variable & Files & Format & Source \\
\hline Fauna attraction & Google Earth & Raster & Google \\
\hline Protected areas & Conservation units & Vector & IBAMA \\
\hline Water body & Hydrography & Vector & SIPAM \\
\hline Slope & SRTM & Radar & INPE \\
\hline Geology and pedology & Geology/Soils & Vector & CPRM/IBGE \\
\hline Water table & Wells & Vector & SIAGAS \\
\hline Access & Roads & Vector & BDGEX \\
\hline Landfill area & Author (2019) & Numeric & Author (2019) \\
\hline Land use & Sentinel 2 & Raster & USGS \\
\hline Landfill useful life & NBR & Numeric & NBR 13.896/1997 \\
\hline Urban area & Sentinel 2 & Raster & USGS \\
\hline Estimated population & IBGE & Numeric & Author (2019) \\
\hline Estimated waste production & ABRESPE & Numeric & Author (2019) \\
\hline
\end{tabular}

Thirty-meter resolution Shuttle Radar Topography Mission (SRTM) images processed by the National Institute for Space Research (INPE) were used to obtain slope data. Information about Geology was provided by the Mineral Resources Research Company (CPRM) and pedology data were acquired in the RADAM project (2004) on the website of the Brazilian Institute for Geography and Statistics (IBGE).

Water table depth data were retrieved from the Water Table Information System (SIAGAS) website, provided by CPRM. Water table information was accessed from the digital platform of SIAGAS is made available in a Geographic Information System (GIS). A total of 1,688 wells registered in the study area were used to analyze the water table depth through the static water level. Then, the Inverse Distance 
Weighted (IDW) method was used for the spatialization of the water table depth data. This geostatistical method uses mathematical equations for an equal distribution of points for data spatialization with precision and quality, and has been widely used for data interpolation (GARDIMAN, DE FREITAS \& CECILIO, 2012).

In the economic criterion, access data, which refer to roads, were obtained from the Brazilian Army Geoportal BDGEX website. Landfill area and useful life were determined based on population size and waste production, according to social criteria. Two Sentinel 2 Satellite images of the 22MGD and 22MHD point orbits were used for the analysis of land use. They had a 10-meter spatial resolution and 2R3G4B color composition, and were obtained from the American Geological Survey (USGS) on October 20, 2018. The software Ecognition Developer 64 was used for this analysis, and 5 classes were established: Urban Area, Water Body, Forest, Clouds and Pastures. The identification and quantitative analysis of land use data was performed using the segmentation technique. This method consists of a group of pixels that have similar characteristics and thus can determine the type of class (ZHOU et al., 2012).

As to the social criterion, the urban area was delimited with the aid of Sentinel 2 images, based on the land use data generated with them. To estimates of population and waste production, the equations (1) and (2), respectively, were used. The estimated population of the MRB for the year 2034 was based on the works of Carrilho; Candido \& Souza (2017) and Luz et al. (2017). Growth rates were based on the 2010 IBGE demographic census. This method uses the population growth rate of the last demographic census, according to the equation below.

$$
P_{x}=P_{i} *(1+d) \wedge t
$$

Where:

$P_{x}=$ population to be estimated;

$\mathrm{P}_{\mathrm{i}}=$ current population;

$\mathrm{d}=$ annual growth rate

$\mathrm{t}=$ time in years. 
According to the legislation, the landfill must meet a waste production of at least 10 years. Thus, the present study adopted a useful life of 15 years. The product of the estimated population by the annual average production of solid waste/inhabitant of $0.640 \mathrm{~kg} / \mathrm{inh} a b . /$ day was used to estimate the production of solid waste by 2034 (ABRELPE, 2016).

$$
\operatorname{Prs}=P . R s
$$

Prs = estimated solid waste production (2034);

$\mathrm{P}=$ population in the year 2034;

Rs = annual average solid waste production/inhabitant

The methodology of Baierle et al. (2016) was used to estimate the daily volume of waste produced (Vrs). First, the amount of waste produced was multiplied by its specific weight value $\left(700 \mathrm{~kg} \backslash \mathrm{m}^{3}\right)$ (equation III). This specific weight value was also found in the works of Lourenço et al. (2015) and Baierle et al. (2016).

$$
\text { Vrs }=\frac{\text { Prs } * 365 * \text { Vida Útil }}{\text { Peso Especifico }}
$$

To calculate the minimum landfill area, the ratio between the volume of waste produced (Vrs) and the maximum height ( $\mathrm{h}$ ) of stacked waste is estimated (equation 4) (MOREIRA et al., 2016).

$$
\text { Area }=\frac{\mathrm{Vrs}}{\mathrm{h}}
$$


Figure 2 - Flowchart of the methodology for selecting potential areas for landfill installation

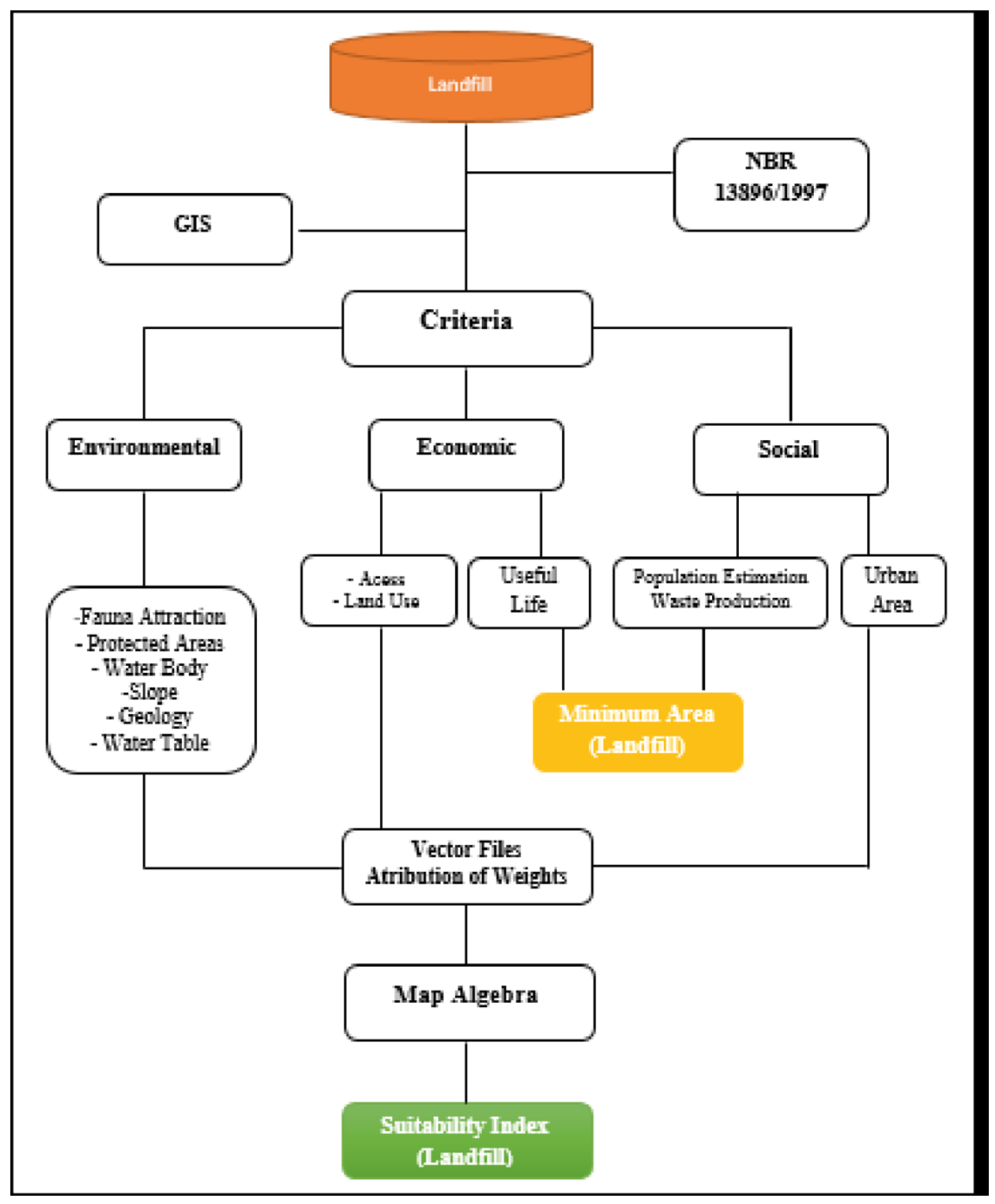

\subsection{Map algebra}

For data spatialization, we worked in a GIS environment using map algebra operations to generate a Suitability Index that indicates suitable areas for potential installation of a landfill. To this end, the variables access, urban area, water body, slope, geology, water table, pedology and land use were transformed into vector data. For each variable used based on the adopted criteria, a weight ranging from 1 to 10 
was assigned; 1 indicated the most unsuitable areas and 10 the most suitable areas for landfill installation (Table 1). Then, a weight was attributed to the suitability index according to Lourenço et al. (2015) to generate a final value according to equation (5). The UTM coordinate system and Datum SIRGAS 2000 spindle 23 South was used in this research and the data were processed in the Arcgis $10.5^{\circledR}$ software.

Table 1 - Weight distribution for each variable of the adopted criteria

\begin{tabular}{|c|c|c|c|}
\hline Access & Weight & Water body & Weight \\
\hline 100 - 200 Meters & 10 & 200 Meters & 1 \\
\hline 200 - 400 Meters & 8 & 200 - 400 Meters & 4 \\
\hline 400 - 600 Meters & 6 & 400 - 600 Meters & 6 \\
\hline 600 - 800 Meters & 4 & 600 - 800 Meters & 8 \\
\hline 800 - 1000 Meters & 2 & 800 - 1000 Meters & 10 \\
\hline Slope (\%) & Weight & Land use & Weight \\
\hline $0-5$ & 10 & Water body & 1 \\
\hline $5-15$ & 8 & Urban area & 1 \\
\hline $15-25$ & 6 & Forest & 1 \\
\hline $25-45$ & 4 & Deforested Area & 10 \\
\hline$>45$ & 2 & Clouds & 1 \\
\hline Water table (depth) & Weight & Pedology & Weight \\
\hline 5 Meters & 2 & Spodosol & 2 \\
\hline 5 - 10 Meters & 6 & Gleysol Haplicos & 2 \\
\hline 10 - 15 Meters & 8 & Yellow Latosol & 10 \\
\hline Above 15 Meters & 10 & Plinthosol & 10 \\
\hline Urban area & Weight & Geology & Weight \\
\hline 0 - 2000 Meters & 1 & Barriers Group & 10 \\
\hline 2000 - 5000 Meters & 10 & Alluvial Deposits & 2 \\
\hline 5000 - 8000 Meters & 8 & Post-Barrier Sediments & 4 \\
\hline 8000 - 11000 Meters & 6 & & \\
\hline 11000 - 14000 Meters & 4 & & \\
\hline 14000 - 17000 Meters & 2 & & \\
\hline 17000 - 20000 Meters & 1 & & \\
\hline
\end{tabular}

Source: Adapted from Baierle et al. (2016); Lourenço et al. (2015). 
Table 2 - Weights attributed to the variables used in the research

\begin{tabular}{lc}
\hline Variables & Weight (\%) \\
\hline Access & 10 \\
Urban area & 15 \\
Water body & 10 \\
Slope & 15 \\
Geology & 10 \\
Water table & 10 \\
Soil & 10 \\
Land Use & 20 \\
Total & 100 \\
\hline
\end{tabular}

Source: Lourenço et al. (2015).

$$
\begin{aligned}
& \text { Suitability Index }=0.1 \text { * Access }+0.15 * \text { Urban Area }+0.1 \text { * Water } \\
& \text { Body } 0.15 * \text { Slope }+0.1 \text { * Geology }+0.10 \text { * Water table }+0.1 \text { * } \\
& \text { Pedology }+0.2 * \text { Land use }
\end{aligned}
$$

\section{RESULTS AND DISCUSSION}

\subsection{Social criteria}

The population of Belém estimated for the year 2034 is of 1,657,291 inhabitants. In 2019, according to IBGE, the municipality of Belém had a population of 1,485,732 inhabitants, the largest in the state of Pará (Table 3). Thus, over a 15-year period, an increase of 384,040 people is expected, amounting to a total of $2,676,798$ people. With the disordered growth of Brazilian cities and inefficient public policies, solid waste production has been growing in a disorganized manner (CEZAR et al., 2015).

The amount of solid waste produced in the state of Pará is 1,723.15 tons/day. The planning of the landfill area considered an annual production of 600 thousand tons/year, generating a produced volume of more than 9 million tons of accumulated waste until the year 2034 (Table 3). An important observation is that the municipalities 
of Belém and Ananindeua have the highest daily production of waste: 1060.67 and 405.95 tons/day, respectively. The municipalities of Santa Bárbara and Benevides presented the lowest values: 18.66 and 54.40 tons/day, respectively.

Thus, in order to meet the needs of the MRB, which has a daily production of waste of 1,715.15 tons/day, the landfill must be large. Landfills of up to 100 tons/day are considered small; up to 800 tons/day, medium sized; and around 2000 tons/day, large (ABRETE, 2007). The estimated area for the volume of waste produced in Belém alone totals 138.27 hectares, and the smallest volume produced was of the municipality of Santa Bárbara, requiring an area of 2.43 hectares. The area was estimated according to the needs of each municipality; however, the survey took into consideration only sites larger than 223 hectares as the potential places for the installation of the project.

Table 3 - Population and area estimates for landfill installation

\begin{tabular}{|c|c|c|c|c|c|c|c|c|}
\hline Municipality & $\begin{array}{c}2010 \\
\text { Populati } \\
\text { on } \\
\text { census }\end{array}$ & $\begin{array}{l}\text { Current } \\
\text { Populati } \\
\text { on }\end{array}$ & $\begin{array}{c}\text { Annual } \\
\text { growth } \\
\text { rate }\end{array}$ & $\begin{array}{l}\text { Popul } \\
\text { ation } \\
2034\end{array}$ & $\begin{array}{c}\text { Solid } \\
\text { waste } \\
\text { (tons/ } \\
\text { day) }\end{array}$ & $\begin{array}{l}\text { Solid } \\
\text { waste } \\
\text { (tons/ } \\
\text { year) }\end{array}$ & $\begin{array}{l}\text { Produced } \\
\text { Volume } \\
2034 \text { (tons) }\end{array}$ & $\begin{array}{c}\text { Area } \\
\text { (ha) }\end{array}$ \\
\hline Belém & 1,393,999 & $1,485,732$ & 0.73 & $1,657,291$ & $1,060.67$ & $387,143.29$ & $5,807,149.36$ & 138.27 \\
\hline Ananindeua & 471,980 & 525,566 & 1.26 & 634,296 & 405.95 & $148,171.63$ & $2,222,574.50$ & 0.52 \\
\hline Marituba & 108246 & 129,321 & 2.16 & 178,275 & 114.10 & $41,645.15$ & $624,677.29$ & 14.87 \\
\hline Benevides & 51,651 & 61,689 & 2.15 & 84,992 & 54.40 & $19,854.24$ & $297,813.63$ & 7.09 \\
\hline $\begin{array}{l}\text { Santa } \\
\text { Bárbara }\end{array}$ & 17,141 & 20,704 & 2.30 & 29,160 & 18.66 & $6,811.97$ & $102,179.62$ & 2.43 \\
\hline Santa Isabel & 59,466 & 69,746 & 1.92 & 92,781 & 59.38 & $21,673.77$ & $325,106.52$ & 7.74 \\
\hline Total & $2,104,493$ & $2,292,758$ & - & $2,676,798$ & $1,713.15$ & $625,300.06$ & $9,379,500.93$ & 223.32 \\
\hline
\end{tabular}

According to ABETRE (2007) data, the total budget for a large landfill to be created in the MRB, including pre-installation, installation, operation, closure and post-closure steps is around $R \$ 525$ million, of which about $87 \%$ of the amount is to be used in the operation phase of the project, for a period of 42 years, from the preinstallation phase to the closure of the landfill. 


\subsection{Economic criteria}

As for potential areas for installation of a sanitary landfill according to the variable access, areas at a distance of $1 \mathrm{~km}$ to highways in Pará were considered ineligible because they are busy roads with a large flow of people and cars. Areas at a distance of 100 meters from highways were also considered as restricted. According to Table 4, sites with the highest potential for landfill installation, which were found at distances from 100 to 200 meters, represented $11.56 \%$ of the studied area, and those with the lowest potential, which were at distances above 1000 meters (Figure 3), represented over $60 \%$ of the studied area.

In the criterion urban area, areas up to $5 \mathrm{~km}$ are considered suitable and represented half of the total studied area (51.07\%), with $1,117 \mathrm{~km}^{2}$ (Table 4). The furthest sites, those located at 17,000 to 20,000 meters from urban areas, are less favorable for landfill installation and account for about $4 \%$ of the total studied area. The criteria urban area and access are important in view of the costs involved in transportation of the waste to its final destination, the landfill. The cost analysis evaluates the distance between the generation points and the landfill, always taking into consideration the transportation of the waste (MOREIRA et al., 2016).

\subsection{Ambiental criteria}

Considering the distance from rivers, an area of approximately $474 \mathrm{~km}^{2}$ is unfit for landfill installation due to distances of less than 200 meters from water bodies (Table 4). Areas considered suitable, more than 200 meters distant from water bodies, correspond to $81.31 \%$ of the total studied area, with emphasis on sites whose distance from water bodies is above 1000 meters, which received weight 10 . They correspond to $904.18 \mathrm{~km}^{2}$, and $38.34 \%$ of the total area. Water bodies that are close to landfills are eventually recipients of liquid waste, and this may end up contaminating the water table and water bodies (ROSA et al., 2017).

As for slope, the studied area has five classes, distributed mainly in slopes between 0 and $45 \%$. Most part of the studied area, approximately $84 \%$, is composed of flat surfaces, thus considered suitable for landfills (Table 4, Figure 3). The slope is 
directly related to the installation of erosive processes and landslides (LOURENÇO et al., 2015).

The geology of the studied area is characterized by the Barriers Group, Alluvial Deposits and Post-Barriers sediments and had a 10\% importance degree. The Barriers Group, which received weight 10 and is composed of sandstones and claystones, correspond to $44.27 \%$ of the total area. It is characterized by its capacity to support loads and well-drained sediments (OLIVEIRA, ALVES \& OLIVEIRA, 2012). Alluvial deposits are unfit for landfill installation and, according to Lino (2007), have high susceptibility to flooding. Alluvial deposits correspond to $13 \%$ of the studied area. The class Post-Barriers sediments are sandy-clay soils with pebble layers of rust sandstone (CPRM, 2010), amount for $42.60 \%$ of the total area, and received weight 4 in the analysis. According to Souza \& Anjos (2004), this type of sediment may facilitate the contamination of aquifers and is not recommended for landfill installation.

Areas with water table depths of up to 5 meters, which are unsuitable for landfill installation, corresponded to $440 \mathrm{~km}^{2}$ or $17.33 \%$ of the total area (Table 4). Thus, most of the study area, $82.67 \%$, are areas with depths greater than 5 meters and are therefore considered suitable for the installation of the project. High water table depth is important to avoid possible contamination through leachates (PORTELLA \& RIBEIRO, 2014).

The gleysol and spodosol classes occur in an area of $484.92 \mathrm{~km}^{2}$ and $60.81 \mathrm{~km}^{2}$, respectively (Table 5). They received weight 2 in the analysis due to their limitations regarding drainage and risk of contamination of watercourses and water table. The gleysol class is characterized by the grayish color coming from the floodplain area, and in the spodosol class the soils are sandy (EMBRAPA, 2011). The latosol class had an area of $619.11 \mathrm{~km}^{2}$. It received weight 10 because it is characterized by welldeveloped, deep and well-drained soils (EMBRAPA, 2011). The plintossol class also received weight 10, as it has restricted percolation of water, is located on dry lands, and has a smooth wavy and flat relief, that is, good characteristics for landfill installation (SILVA \& PINHEIRO, 2010). 
Table 4 - Area in $\mathrm{km}^{2}$ and $\%$ of the criteria used in the research

\begin{tabular}{|c|c|c|c|c|c|}
\hline \multirow{2}{*}{ Access } & \multicolumn{2}{|c|}{ Area } & \multirow{2}{*}{ Geology } & \multicolumn{2}{|c|}{ Area } \\
\hline & $\mathbf{k m}^{2}$ & $\%$ & & $\mathrm{~km}^{2}$ & $\%$ \\
\hline $100-200$ & 259.87 & 11.56 & Barriers Group & 846.01 & 44.27 \\
\hline $200-400$ & 239.54 & 10.66 & Alluvial Deposits & 250.58 & 13.11 \\
\hline $600-800$ & 210.08 & 9.35 & $\begin{array}{l}\text { Post-Barrier } \\
\text { Sediment }\end{array}$ & 814.17 & 42.60 \\
\hline $800-1000$ & 171.51 & \multirow{2}{*}{$\begin{array}{c}7.63 \\
60.80\end{array}$} & \multirow{2}{*}{ Water table (depth) } & \multicolumn{2}{|c|}{ Area } \\
\hline$>1000$ & 1366.59 & & & $\mathbf{k m}^{2}$ & $\%$ \\
\hline \multirow{2}{*}{ Urban area } & \multicolumn{2}{|c|}{ Area } & $0-5$ & 846.01 & 440.29 \\
\hline & $\mathrm{km}^{2}$ & $\%$ & $5-10$ & 1766.97 & 69.55 \\
\hline $2000-5000$ & 1117.00 & 51.07 & $10-15$ & 301.25 & 11.86 \\
\hline $5000-8000$ & 436.63 & 19.96 & $>15$ & 31.95 & 1.26 \\
\hline $8000-11000$ & 317.01 & 14.50 & \multirow{2}{*}{ Pedology } & \multicolumn{2}{|c|}{ Area } \\
\hline $11000-14000$ & 173.15 & 7.92 & & $\mathrm{~km}^{2}$ & $\%$ \\
\hline 14000- 17000 & 86.82 & 3.97 & Gleysol & 484.92 & 25.46 \\
\hline $17000-20000$ & 56.39 & 2.58 & Spodosol & 60.81 & 3.19 \\
\hline \multirow{2}{*}{ Water body } & \multicolumn{2}{|c|}{ Area } & Latosol & 1183.58 & 62.13 \\
\hline & $\mathrm{km}^{2}$ & $\%$ & Plinthosol & 175.67 & 9.22 \\
\hline $0-200$ & 474.82 & 18.69 & \multirow[b]{2}{*}{ Land use } & \multicolumn{2}{|c|}{ Area } \\
\hline $200-400$ & 413.58 & 16.27 & & $\mathbf{k m}^{2}$ & $\%$ \\
\hline $400-600$ & 369.18 & 14.53 & Urban area & 224.95 & 8.86 \\
\hline $600-800$ & 308.66 & 12.14 & Water body & 649.98 & 25.59 \\
\hline$>1000$ & 904.18 & 38.34 & Forest & 1215.21 & 47.84 \\
\hline \multirow{2}{*}{ Slope (\%) } & \multicolumn{2}{|c|}{ Area } & $\begin{array}{c}\text { Deforested } \\
\text { Area/Exposed Soil }\end{array}$ & & 14.92 \\
\hline & $\mathrm{km}^{2}$ & $\%$ & Cloud & 70.86 & 2.79 \\
\hline $0-5$ & 2144.01 & 84.38 & & & \\
\hline $5-15$ & 391.91 & 15.42 & & & \\
\hline $15-25$ & 4.63 & 0.18 & & & \\
\hline $25-45$ & 0.13 & 0.005 & & & \\
\hline$>45$ & 0.006 & 0.0002 & & & \\
\hline
\end{tabular}


Five land use classes were identified in the study area (Figure 3). The class "deforested area/exposed soil", considered suitable for installation of the project, corresponded to $14.92 \%$ of the total area. Areas considered inappropriate (urban area, water body, forest, clouds) for landfill installation represented about $85 \%$ of the total area of the MRB (Table 4). Land use areas that were not in accordance with current environmental legislation and with the municipality's master plan were considered non-recommended areas (ZVEIBIL, 2001).

Figure 3 - Map of potential areas for the installation of the landfill in the MRB, in relation to the variables: access, urban area, hydrography, slope, geology, water table, pedology, and land use

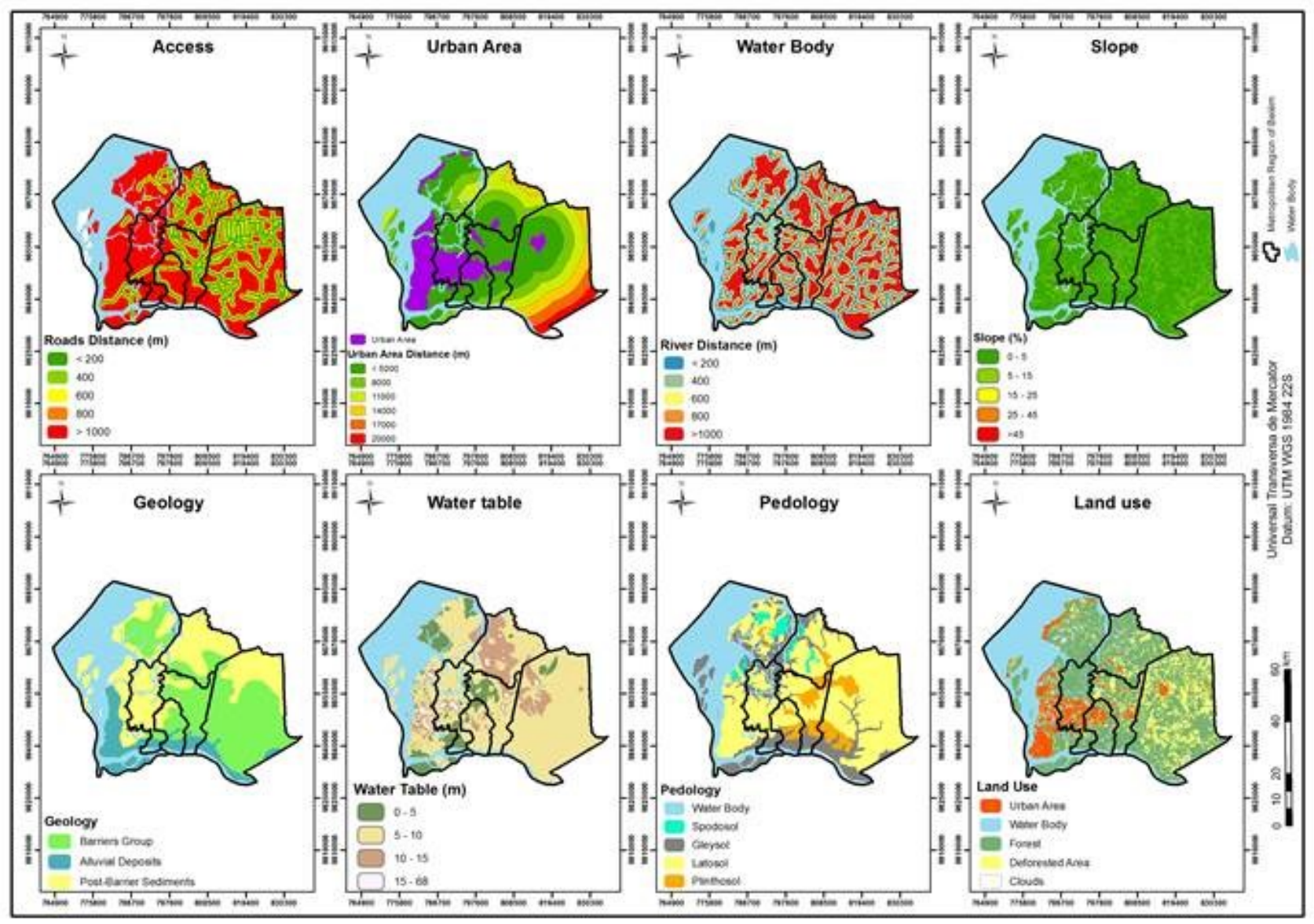

\subsection{Potential areas for sanitary landfill installation}

Four areas were selected for possible installation of a landfill in the MRB. Areas 1 and 2 had an area of 228 and 220 hectares, respectively, and a suitability index of 
8.7 (Table 5). Area 3 had the best index in the analysis (8.9) and an extension of 225 hectares, while area 4 corresponded to a total of 231 hectares and presented a suitability index of 8.8 (Figure 4).

Ineligible areas account for approximately $85 \%$ of the total area of the MRB. They are inadequate due to the presence of protected areas such as the Utinga Park, Combu Island and the Metrópole da Amazônia Wildlife Refuge (Figure 4), and also due to the large amount of water bodies.

Table 5 - Potential areas for landfill installation

\begin{tabular}{lcc}
\hline Potential areas & Area (ha) & Suitability index \\
\hline 1 & 228 & 8.7 \\
2 & 220 & 8.7 \\
3 & 225 & 8.9 \\
4 & 231 & 8.5 \\
\hline
\end{tabular}

Figure 4 - Suitability index for the installation of the landfill in the MRB

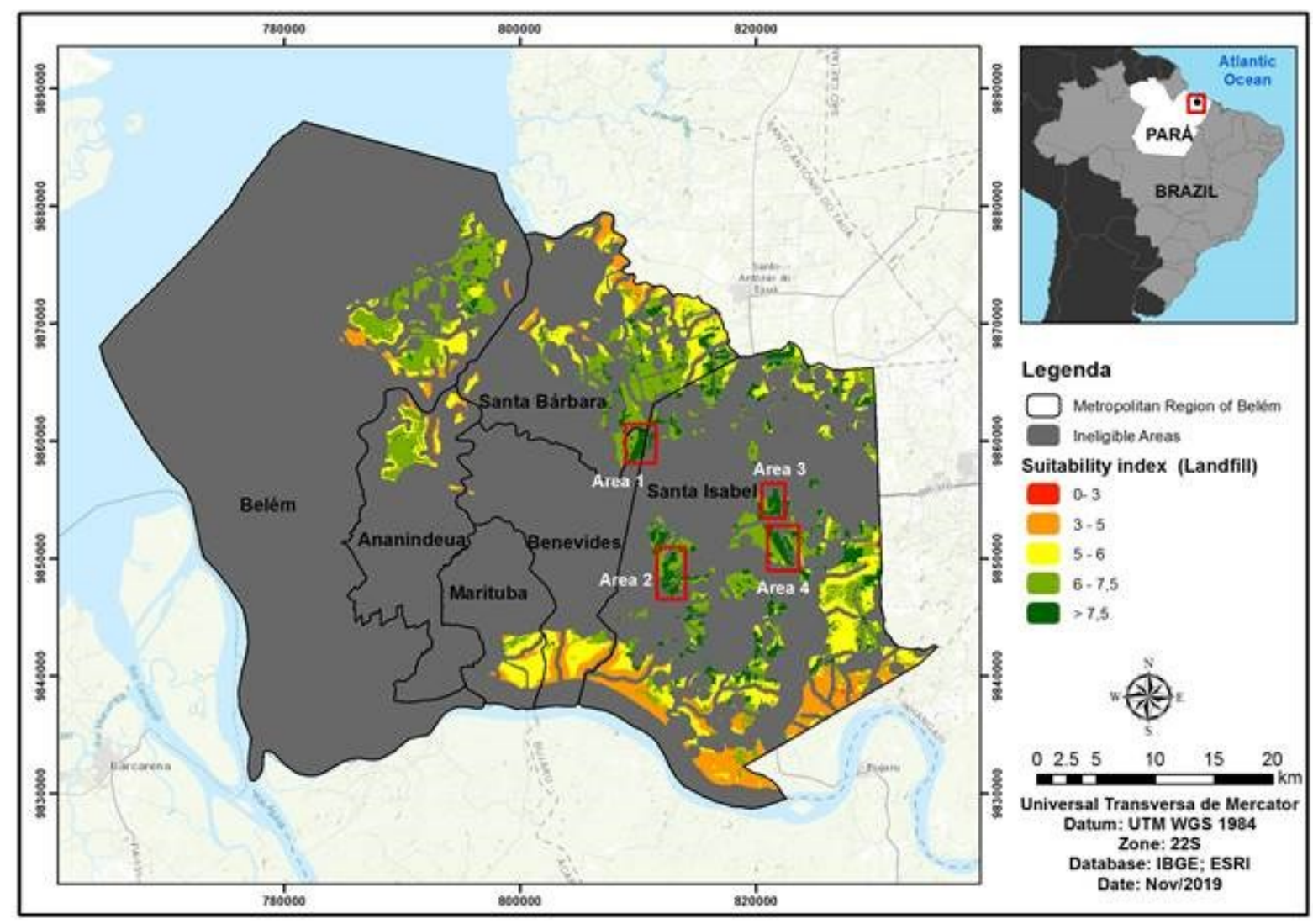


Based on the amount of waste generated in the MRB, the municipalities of Belém and Ananindeua are the ones that most need areas for landfill installation. However, these municipalities did not have suitable areas for the installation of the project. Area 1 is located between the municipalities of Benevides, Santa Bárbara and Santa Isabel and the other areas are in the municipality of Santa Isabel.

Importantly, the smallest distance between the closest area (area 1) and the city of Belém, the municipality with the largest amount of waste generated, is approximately 35 km. Carrilo, Candido \& Souza (2015) and Gomes et al. (2018) stress that a distance of up to $20 \mathrm{~km}$ is recommended, because of the cost of moving vehicles to the landfill. Thus, an alternative would be the leasing of transhipment stations for the disposal of waste in places where the distance to the landfill is greater than $20 \mathrm{~km}$ (NUNES \& SILVA, 2015).

Figure 5 - Areas selected for landfill installation
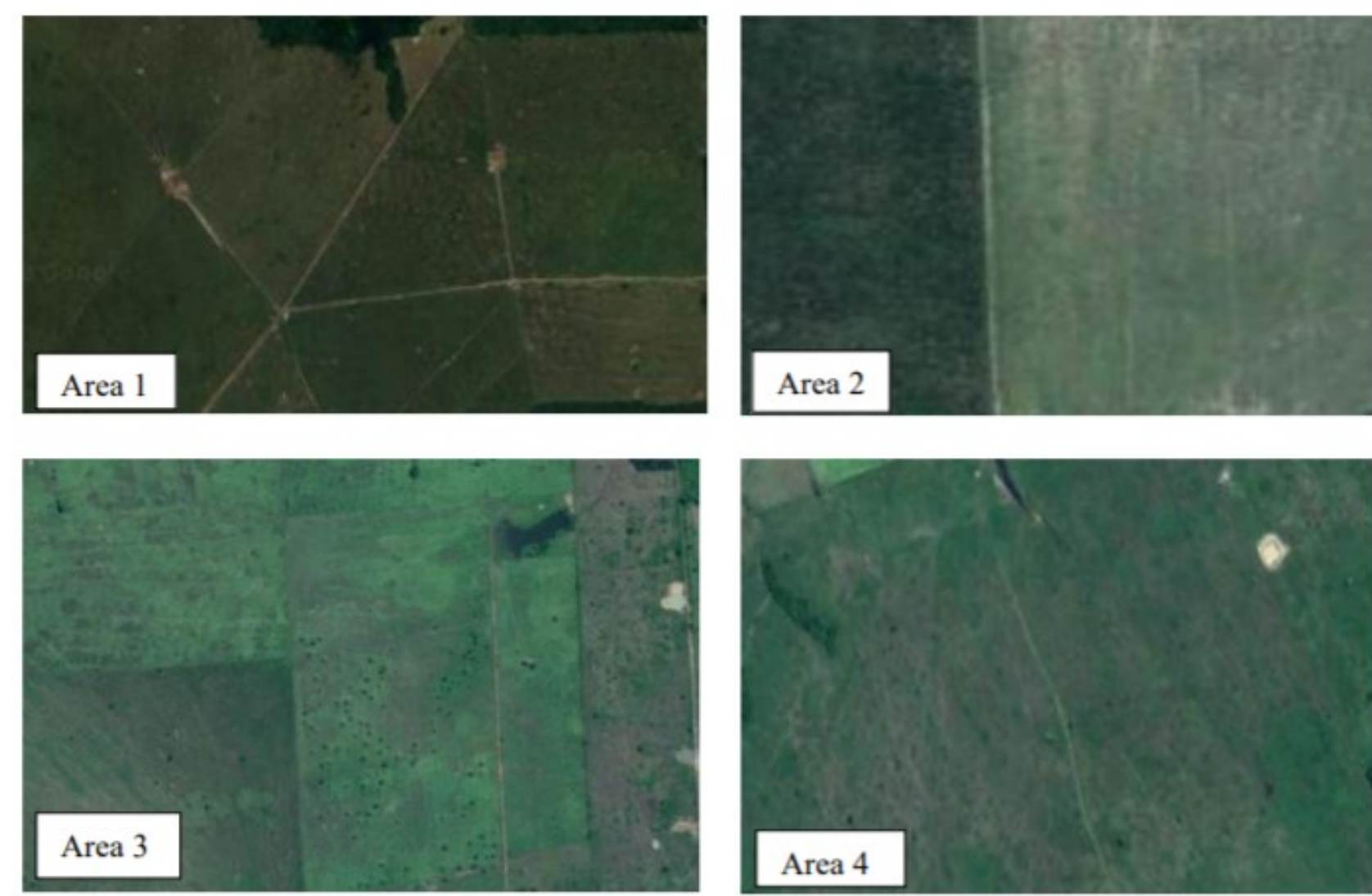
The areas indicated for landfill installation (Figure 5), according to the territorial dimension necessary to meet the population demand until 2034, are located in flat terrains with exposed soil, ideal for the implementation of the project. They are also located near highways, so as to facilitate the transport of solid waste to its final disposal in the landfill. According to the National Environmental Registry System (SICAR), the selected areas are located in private properties.

Importantly, other areas also had good levels of suitability for landfill installation, but have less than 214 hectares and do not meet the MRB population demand.

\section{CONCLUSIONS}

The methodology used in the research allowed selecting potential areas for the installation of a sanitary landfill, using geoprocessing techniques, according to the restriction criteria of NBR 13896/1997, considering the necessary size to meet the solid waste production in the region, access roads, topography, water bodies, useful life, and types of land use.

Four areas were considered suitable for landfill installation in the MRB as they met the criteria established by law. However, although the methodology was effective, the use of geoprocessing has some limitations; field validation is necessary because some information is not available in digital spatial data.

Other important variables need to be considered for the analysis of favorable areas for landfill installation, such as wind direction, to avoid the odor to reach urban areas. It is also necessary to analyze the permeability in loco, to test the velocity and flow efficiency of the percolated liquids in the soil for drainage installation. Therefore, following the verification of potential areas for landfill installation through geoprocessing techniques, further analysis for the final selection is of paramount importance. 


\section{REFERENCES}

ABRELPE - ASSOCIAÇÃO BRASILEIRA DE EMPRESAS DE LIMPEZA PÚBLICA E RESÍDUOS ESPECIAIS [Internet]. Geração de lixo no Brasil aumentou cinco vezes mais do que a população. 2016. [cited 2019 Mar 20]. Available from: http://oglobo.globo.com/soiedade/sustentabilidade/geracao-de-lixo-no-brasilaumentou-cinco-vezes-mais-do-que-populacao-16926042. Access in: 20 Mar de 2019.

ABRETE - ASSOCIAÇÃO BRASILEIRA DE EMPRESAS DE TRATAMENTO DE RESIDUOS. Estudos sobre os Aspectos Econômicos e Financeiros da Implantação e Operação de Aterros Sanitários. Fundação Getúlio Vargas - FGV. 2007. [cited 2019 Ap 02]. Available from: http://www.abetre.org.br/estudos-e-publicacoes/publicacoes/publicacoesabetre/FGV\%20 \%20Aterros\%20Sanitarios\%20-\%20Estudo.pdf.

ABNT, ASSOCIAÇÃO BRASILEIRA DE NORMAS TÉCNICAS. NBR 13896/1997: Aterros de resíduos não perigosos - Critérios para projeto, implantação e operação. Rio de Janeiro, RJ, 1997.

ABNT, ASSOCIAÇÃO BRASILEIRA DE NORMAS TÉCNICAS. NBR 8.419/1992: Apresentação de projetos de aterros

sanitários de resíduos sólidos urbanos. Rio de Janeiro, RJ, 1992.

ABNT, ASSOCIAÇÃO BRASILEIRA DE NORMAS TÉCNICAS. NBR 15.849/2010: Resíduos sólidos urbanos - Aterros sanitários de pequeno porte - Diretrizes para localização, projeto, implantação, operação e encerramento. Rio de Janeiro, RJ, 2010.

BAIERLE, B; MUNIZ, M. S., TOMAZONI, J. C., \& MANOSSO, F. C. Seleção de área adequada para a implantação de aterro sanitário no município de Marmeleiro - PR, através de técnicas de geoprocessamento. Engenharia Ambiental - Espírito Santo do Pinhal, jul./dez. 2016. v. 13, n. 2 p. $110-127$.

BRASIL. Lei $n^{\circ} 12.305$ de 2 de agosto de 2010. Institui a Política Nacional de Resíduos Sólidos. Diário Oficial [da] república Federativa do Brasil, Brasília, DF, 3 ago. 2010.

CARRILHO, A, N; CANDIDO, H, G; SOUZA, A, D. Geoprocessamento aplicado na seleção de áreas para a implantação de aterro sanitário no município de Conceição das Alagoas-MG. Engenharia Sanitária e Ambiental, 2018, v. 23, n. 1. Pag 201 - 206.

CEZAR, L, C, BARBOSA, T. R. D. C. G., REIS, M. C. T., \& DA FONSECA JÚNIOR, F. Panorama Acadêmico sobre Resíduos Sólidos: Análise da produção cientifica a partir do marco legal do setor. Revista Metropolitana de Sustentabilidade (ISSN 2318-3233), 2015, v. 5, n. 2, p. 14-33.

CORREIA, V. M. S., DE AQUINO, M. D., THOMAZ, A. C. F., \& CORREIA, M. L. V. Estudo de caso: aspectos e impactos perceptíveis na localização de lixões municipais utilizando a ferramenta M-MACBETH. Revista DAE, 2017, núm. 211.vol. 66.p. 35 - 49. 
COSTA, Marco, A, C. Caracterização e quadros de análise comparativa da governança metropolitana no Brasil: arranjos institucionais de gestão metropolitana (Componente 1): região metropolitana de Belém. Relatório de Pesquisa. Insituto de Pesquisa Econômica Aplicada - IPEA. 2015. [cited 2019 Mai 02]. Available from: http://www.ipea.gov.br/portal/images/stories/PDFs/relatoriopesquisa/rel_1_1_rm_bele m.pdf.

CPRM - Companhia de Pesquisa de Recursos Minerais - GEOBANK [Internet], Dados, Informações e Produto do Serviço Geológico do Brasil. 2013. [cited 2019 Mai 07]. Available from: http://geosgb.cprm.gov.br/.

DANTAS, G.S.; LOPES, S.R.M.; PONTES, A.N. Lixão do Aurá em Belém-Pa e a política nacional de resíduos sólidos: tratamento jurídico dado aos catadores. Revista Eletrônica Direito e Política, 2015 v.10, n.3, p. 2017-2049.

EMBRAPA Solos: relatório de gestão/atividades 2011/Embrapa Solos. -- Rio de Janeiro: Embrapa Solos,.; il. - (Documentos/Embrapa Solos, ISSN 1517-2627 ; 131), 2011. 96 p.

FELICORI, T.C.; MARQUES, E.A.G.; SILVA, T.Q.; PORTO, B.B.; BRAVIN, T.C.; SANTOS, K.M.C. Identificação de áreas adequadas para a construção de aterros sanitários e usinas de triagem e compostagem na mesorregião da Zona da Mata, Minas Gerais. Eng Sanit Ambient, 2016, v.21, n.3, p.547-560.

GARDIMAN, B. S., MAGALHÃES, I. A. L., DE FREITAS, C. A. A., \& CECÍLIO, R. A. Análise de técnicas de interpolação para espacialização da precipitação pluvial na bacia do rio Itapemirim (ES). Ambiência, 2012, 8(1),p. 61-71.

GOMES, L. P., KOHL, C. A., SOUZA, C. L. D. L., REMPEL, N., MIRANDA, L. A. S., \& MORAES, C. A. M. Avaliação ambiental de aterros sanitários de resíduos sólidos urbanos precedidos ou não por unidades de compostagem. Engenharia Sanitaria e Ambiental, 2015, v. 20, n. 3, p. 449-462.

IBGE - INSTITUTO BRASILEIRO DE GEOGRAFIA E ESTATÍSTICA [Internet]. 2010 [cited 2019 apr 15]. Avaliable from: http://biblioteca.ibge.gov.br/visualizacao/dtbs/para/castanhal.pdf.

IBGE - INSTITUTO BRASILEIRO DE GEOGRAFIA E ESTATÍ́STICA [Internet]. Mudança Demográfica no Brasil no Início do Século XXI. 2015 [cited 2019 ap 13]. Avaliable from: http://biblioteca.ibge.gov.br/visualizacao/livros/liv93322.pdf

IBGE - INSTITUTO BRASILEIRO DE GEOGRAFIA E ESTATÍSTICA [Internet]. RADAMBRASIL. Rio de Janeiro: IBGE, 2010. [cited 2019 ap 10]. Avaliable from: ftp://geoftp.ibge.gov.br/cartas_e_mapas/bases_cartograficas_continuas/bcim/.

IBAM. MANUAL GERENCIAMENTO INTEGRADO DE RESÍDUOS SÓLIDOS. [Internet]. Rio de Janeiro, 2001. p. 149. [cited 2019 Mar 10]. Avaliable from: http://www.resol.com.br/cartilha4/manual.pdf. 
JUNIOR, M.R.V.; CORREAA, R.S.S. Resíduos sólidos urbanos e sustentabilidade: desafios da implantação do aterro sanitário de Marituba - Pa. Anais ERESPP, 2017, v.1.

LOURENÇO, R. W.; SILVA, D. C. C.; SALES, J. C. A.; MEDEIROS, G. A.; OTERO, R. A. P. Metodologia para seleção de áreas aptas à instalação de aterros sanitários consorciados utilizando SIG. Ciência e Natura, Santa Maria, v. 37 n. 4 set-dez. 2015, p. 122-140.

LUZ, E., MARION, F. A., FRANÇA, M. M., \& DA CONCEIÇÃ̃, P. S. Utilização de Sistema de Informação Geográfica para identificação de áreas potenciais à implantação de aterro sanitário consorciado. AMBIÊNCIA, 2017, v. 13, n. 2, p. 452-469.

MORAES, I, S; FERREIRA, H, S.; OLIVEIRA, S, F, C. A utilização do sig como ferramenta para indicação de áreas possíveis a implantação de aterro sanitário na região metropolitana de Belém-PA. III Simpósio Brasileiro de Ciências Geodésias e Tecnologias da Geoinformação, p. 27-30, 2010.

MOREIRA, L. L., SCHWAMBACK, D., CORRÊA, N. R., \& COELHO, A. L. N. Sig aplicado à seleção de áreas potenciais para instalação de aterro sanitário no município de serraES. Geociências (São Paulo), 2016, 35(4), p. 531-541.

NAS, B.; CAY, T.; ISCAN, F.; BERKTAY, A. Selection of MSW landfill site for Konya, Turkey using GIS and multi-criteria evaluation. Environ Monit Assess, 2010, 160:491-500.

NUNES, R. R., \& DA SILVA, E. R. A. P. Transbordo de resíduos sólidos. Revista Pensar Engenharia, 2015. V.3, n.1. 18 p.

OLIVEIRA, F, B; DA GLÓRIA ALVES, M; DE OLIVEIRA, C, H, R, Favorabilidade de áreas para implantação de aterros controlados no município de Campos dos Goytacazes/RJ utilizando sistema de informação geográfica. Revista Brasileira de Cartografia, 2012. n 64, p $33-44$.

PORTELLA, M, O,; RIBEIRO, J, C, J.. Aterros sanitários: aspectos gerais e destino final dos resíduos. Revista Direito Ambiental e Sociedade, 2014, v. 4, n. 1. P 115 - 134.

REZENDE, F.S.; LEITE, M.B.A.; CARRIELO, F. Áreas potenciais para implantação de aterro sanitário em Ilha Grande - RJ. In: Simpósio Brasileiro de Sensoriamento Remoto, 17., 2015. João Pessoa. Anais... João Pessoa: INPE, 2015. 4754 - 4761.

SANTO, V.C.P. Aurá de Gentes, Lixo e Água: Ação Pública e Racionalidades em confronto em Belém (PA). Revista de Direito da Cidade, 2014, v.6, n.1, p. 65-89.

SANTOS, M, R, S. A Precipitação climática na mesorregião metropolitana de Belém e suas implicações socioambientais. [dissertation]. Belém/PA. Universidade Federal do Pará. 2017. 142 p.

SILVA, M. C. C.; PELÁ, A.; BARRETOS, F.R.M. Impactos ambientais na destinação inadequada de resíduos sólidos urbanos na cidade de Ipameri-GO: um estudo de 
caso. Revista Eletrônica em Gestão, Educação e Tecnologia Ambiental, 2013, v.17, n.17, p. 3230-3239.

SILVA, C.; SCHOENHALS, M.; CORNELI, V.M.; ARANTES, E.J. Diagnóstico da contaminação do solo e aplicação do índice de qualidade de aterros de resíduos da Cetesb na área de disposição de resíduos sólidos urbanos de Peabirú-PR. Engenharia Ambiental, 2012, v. 9, n. 2, p. 252-270.

SILVA, Alexandre Donato; PINHEIRO, Eduardo da Silva. A Problemática dos Resíduos Sólidos Urbanos em Tefé, Amazonas. Sociedade \& Natureza, Uberlândia, 2010, 22 (2), p. 297-312.

SCHMIDT, Tanara. Seleção de área e dimensionamento de aterro sanitário para o consórcio público intermunicipal para assuntos estratégicos do G8-CIPAE G8. 2017. [monography]. Lajeado. Centro Universitário Univates. 2017. 145 p.

SOUZA, E, L. ANJOS, G, C. Contaminação das Águas Subterrâneas: Uma Visão Parcial da Situação de Belém e dos Problemas Decorrentes. In: UHLY, S. \& SOUZA, E. L. (orgs). A questão da água na grande Belém. Casa de estudos Germânicos, Fundação Heinriche Böll. 2004. 151 - 180 p.

VASCONCELOS, J.M.R.; SILVA, C.R.S. Impactos socioambientais causados pelo aterro sanitário no município de Marituba-PA. In: Seminário Nacional de Serviço Social, Trabalho e Políticas Sociais, 2., 2017. Florianópolis. Anais... Florianópolis: UFSC, 2017. $10 \mathrm{p}$.

ZVEIBIL, Victor Zular. Manual de gerenciamento integrado de resíduos sólidos. IBAM. 2001. [Internet]. 2001. p. 149. [cited 2019 Ap 10]. Avaliable from: http://www.resol.com.br/cartilha4/manual.pdf.

ZHOU, Xiaocheng. et al. Urban Land Cover Mapping Based on Object Oriented Classification Using WorldView 2 Satellite Remote Sensing Images. International Scientific Conference on Sustainable Development \& Ecological Footprint. Soprom, Hungary. 2012. 10 p. 